\begin{tabular}{|l|l|l||}
\hline \multicolumn{2}{|c|}{ PublisherInfo } \\
\hline \hline PublisherName & $:$ & BioMed Central \\
\hline \hline PublisherLocation & $:$ & London \\
\hline \hline PublisherImprintName & $:$ & BioMed Central \\
\hline \hline
\end{tabular}

\title{
Novel vector improves efficiency of gene transfer to the airway epithelium
}

\begin{tabular}{||l|l|l||}
\hline \multicolumn{2}{|c||}{ ArticleInfo } \\
\hline \hline ArticleID & $:$ & 1619 \\
\hline \hline ArticleDOI & $:$ & $10.1186 /$ rr-2001-68535 \\
\hline \hline ArticleCitationID & $:$ & 68535 \\
\hline \hline ArticleSequenceNumber & $:$ & 30 \\
\hline \hline ArticleCategory & $:$ & Paper Report \\
\hline \hline ArticleFirstPage & $:$ & 1 \\
\hline \hline ArticleLastPage & $:$ & 3 \\
\hline \hline & & RegistrationDate $: 2001-9-18$ \\
& $:$ & Received $\quad: 2001-9-18$ \\
ArticleHistory & Accepted $\quad: 2001-9-18$ \\
& $:$ & OnlineDate $\quad: 2000-12-21$ \\
\hline \hline ArticleCopyright & $:$ & Biomed Central Ltd2001 \\
\hline \hline ArticleGrants & $:$ & \\
\hline \hline ArticleContext & $:$ & 129312211 \\
\hline \hline
\end{tabular}


Raymond Pickles, ${ }^{\text {Affl }}$

Corresponding Affiliation: Aff1

Aff1 The CF Center, The University of North Carolina at Chapel Hill, NC, USA

\section{Keywords}

$\mathrm{CF}$, gene therapy, $\mathrm{SeV}$

\section{Context}

Gene therapy strategies for the treatment of cystic fibrosis (CF) lung disease have been hindered by the low gene transfer efficiency with which currently available vectors (eg adenovirus, liposomes, retrovirus) deliver transgenes to the airway epithelium in vivo. This inefficiency is mainly due to the inability of lumenally delivered vectors to attach to and enter the epithelial cells that line the airways, which in turn reflects the lack of the necessary vector receptors at the lumenal surface. This study describes the use of a new vector type, the Sendai virus $(\mathrm{SeV})$, which displays high efficiency gene transfer in a number of experimental airway models and suggests that this vector may be useful for gene delivery to the lung.

\section{Significant findings}

The efficiencies with which $\mathrm{SeV}$ vectors can deliver transgenes to airway cells was compared with adenoviral and liposomal vectors. These vectors were tested in a number of models of respiratory airway epithelial cells: freshly isolated human nasal epithelial cells and excised sheep airway epithelium in vitro, and murine and ferret airways in vivo. The authors report that $\mathrm{SeV}$ produced 3-4 logs greater gene transfer efficiencies to the epithelial cells in all the models tested when compared to adenoviral and liposomal vectors. In fact, in vivo, the authors show data demonstrating that $70-80 \%$ of airway epithelial cells express transgenes, an efficiency that surpasses any previously reported studies with viral vectors in the large airways of in vivo models. Furthermore, the authors show that the airway mucus barrier does not impede vector access to the cells, and that, in contrast to other vectors, the exposure time of $\mathrm{SeV}$ to 
the epithelium can be brief. In addition, although limited, the study attempts to describe the airway inflammation caused by administration of this vector.

\section{Comments}

This current work represents a major advance in the development of a gene therapy strategy for CF lung disease, since it demonstrates that a major obstacle to the success of this approach, the efficiency of gene transfer, is surmountable. The study is, however, preliminary since the vectors used are replicationcompetent, and further studies will be required with replication-deficient vectors to confirm the current findings if this system is to be clinically feasible. Another issue is the lower gene transfer efficiency observed in human cells than in murine and ferret cells. Since $\mathrm{SeV}$ is a paramyxovirus that usually infects rodents, it remains to be seen whether this virus is as efficacious in human airways as the animal data suggest. Nonetheless, this study represents an important breakthrough in the field of CF lung gene transfer. Such advances in the basic understanding of these new therapeutic approaches are crucial to developing strategies to aid in the treatment of genetic defects of the lung epithelium.

\section{Methods}

Gene transfer, recombinant vectors, airway epithelium models

\section{Additional information}

\section{References}

1. Yonemitsu Y, Kitson C, Ferrari S, Farley R, Griesenbach U, Judd D, Steel R, Scheid P, Zhu J, Jeffrey P, Kato A, Hasan M, Nagai Y, Masaki I, Fukumura M, Geddes D, Alton E: Efficient gene transfer to airway epithelium using recombinant Sendai virus. Nat Biotechnol . 2000, 18: 970-973.

This PDF file was created after publication. 